\title{
PURPLE AFTER ADALIMUMAB: A CASE REPORT
}

\begin{abstract}
Barbara Ferraço Dalmaso ${ }^{1, \star}$, Ketty Lysie Libardi Lira Machado ${ }^{1}$, Matheus Pereira Rosi ${ }^{1}$, Bárbara Oliveira Souza ${ }^{1}$, Tiago Barcelos da Silva ${ }^{1}$, Luiza Lorenzoni Grillo ${ }^{1}$, Guilherme Vallin Garcia ${ }^{1}$, Laura Gonçalves Aguiar ${ }^{1}$, Heitor Filipe Surlo, Laís Pizzol Pasti ${ }^{1}$, Paula dos Santos Athayde ${ }^{1}$, Mariana de Oliveira Macabú1, João Peçanha Schwartz ${ }^{1}$, Fernanda Sales Soares de Oliveira ${ }^{1}$, Hellen Carvalho Ribeiro ${ }^{1}$, João Victor Cornachini ${ }^{1}$, Anna Carolina Simões Moulin ${ }^{1}$, Raiza Cansian Tuão ${ }^{1}$, Débora Marques Veghini ${ }^{1}$, Gustavo Pinto de Oliveira Gomes ${ }^{1}$, Weider Andrade Tomé1, Luiza Vallory Alochio1 ${ }^{1}$, Luiza Correa Rodrigues Dalpiero ${ }^{1}$, Ruben Horst Duque ${ }^{1}$, Valquíria Garcia Dinis ${ }^{1}$, Elisabeth Lima Marques de Aguiar ${ }^{1}$, Estephania Pignaton Naseri ${ }^{1}$, Bárbara Petronetto Fafá Fardin ${ }^{1}$, Érica Vieira Serrano ${ }^{1}$, Valéria Valim ${ }^{1}$
\end{abstract}

1.Universidade Federal do Espírito Santo, Vitória (ES), Brazil.

${ }^{*}$ Corresponding author: babi_dalmaso@hotmail.com

\section{BACKGROUND}

Crohn's disease $(C D)$ is an inflammatory bowel disease in any portion of the luminal gastrointestinal tract. Drugs used for $C D$ treatment can cause adverse reactions such as vasculitis. A common histologic finding of drug-related is eosinophilic leukocytoclasia vasculitis. Vasculitis related patients with CD might also occur and usually presents as necrotizing small vessels. In this report we show the case of a patient with CD who developed eosinophilic leukocytoclastic vasculitis on her lower limbs.

\section{CASE REPORT}

A 72-year-old white female diagnosed with CD in 2003 (Montreal's classification: A3, L3 and B2p), previous contact with virus B, arterial hypertension and type 2 diabetes mellitus, started treatment with adalimumab 1 ampoule/week in January 2012 for disease activity control. In August 2020, she reported the onset of skin itching associated with painful palpable purpuras on the lower limbs (Figure 1). A diagnostic hypothesis of small vessel vasculitis was raised, and ANCA, cryoglobulinemia, ANA, anti-DNA, rheumatoid factor were negative. In December 2020, she used topical clobetasol and neomycin without improvement, being subsequently started prednisone $20 \mathrm{mg} /$ day. Following it, a skin biopsy was performed, showing leukocytoclastic vasculitis with eosinophil, suggesting a drug-related vasculitis. Systemic corticosteroid therapy was maintained and two pulse therapies were performed with methylprednisolone $500 \mathrm{mg}$. Despite corticosteroid therapy, the lesions and clinical status impaired. The medical team decided to withdraw adalimumab because of suspected drug reaction. After four weeks, patient had a significant improvement, without recurrence.

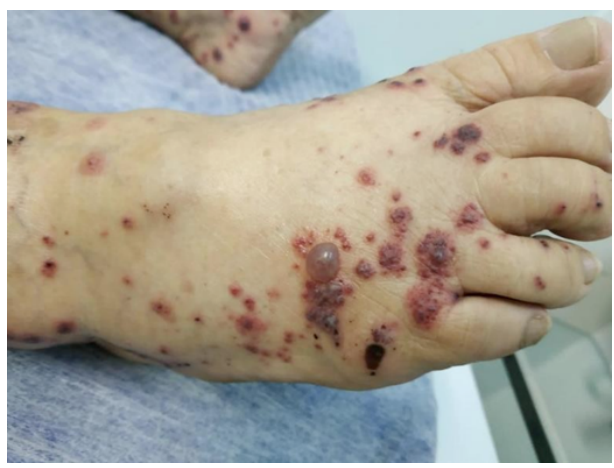

Figure 1. Erythematous purpura in scattered serohemorrhagic plaques.

\section{CONCLUSION}

Vasculitis is an inflammatory process immunologically mediated, determining functional and structural damage to the vessel wall. Cutaneous vasculitis in patients with CD usually presents as necrotizing small vessels. In the case reported here, a patient with $\mathrm{CD}$ developed eosinophilic leukocytoclastic vasculitis under using of adalimumab. In the literature there are reports of this type of vasculitis with the use of these medication, which corroborates the hypothesis of pharmacodermia.

\section{KEYWORDS}

Crohn's disease, Eosinophilic leukocytoclasia vasculitis, Adalimumab, Vasculitis. 